No end of blame on costs

\section{Washington}

CONGRESSIONAL staff are investigating financial records at six US universities as part of a widening probe of academic research costs, officials revealed last week.

In the wake of an investigation of accounting practices at Stanford University that found some $\$ 160$ million in questionable research costs since 1983, the congressional General Accounting Office (GAO) is preparing to audit the Harvard University Medical School, the Massachusetts Institute of Technology, the University of California at Berkeley, the University of Southern California and the University of Pennsylvania. Johns Hopkins University may also be audited, GAO officials said last week.

The investigators are focusing on 'indirect costs' - the fraction of government research funding that universities use to pay for overhead costs such as utilities, library costs and other expenses that are not directly for research itself (see Nature 349, 361; 31 January 1991). In the past decade, indirect costs at most US universities have grown far faster than the 'direct' costs of the research, a situation that has placed academic researchers in competition with their own administrators over scarce research funds.

Harvard University Medical School, for example, has proposed an indirect cost rate of nearly 100 per cent of direct research costs this year. If approved, that would mean that for every federal research dollar the university receives, it would bill the government for another dollar of overhead. Indirect costs at most other private universities range from about 50 to 75 per cent of direct costs.

At a congressional hearing last week, Representative John Dingell (Democrat, Michigan), chairman of the House Energy and Commerce oversight and investigations subcommittee, annuunced the results of a new $\mathrm{GAO}$ probe into accounting practices at Stanford University, which has one of the highest indirect cost rates -70 per cent.

"It is important to understand that, when a university mischarges or overcharges the government for indirect costs", Dingell said, "that has the effect of diverting federal money directly from other high-priority research projects that could have been funded with the wasted money."

Stanford, which over the past three months has been the target of an expanding investigation that has revealed improper charges for, among other things, a yacht, flowers and an antique fruitwood commode, has received a total of about $\$ 1,800$ million in federal research dollars in the past decade. Of that, some \$164-200 million in indirect costs fell under a blanket of special exemptions to normal accounting rules, the GAO investigators found.

"We chose Stanford as the subcommittee's first case study because of a combination of its high overhead rate (it requested 78

per cent this year) and the complaints of the faculty about that rate", Dingell said. After examining Stanford's financial records, he said, investigators found "a story of excess and arrogance, compounded by lax government oversight".

Since the beginning of the investigation late last year, Stanford has agreed to return $\$ 700,000$ in questionable billings, has retained a private accounting firm to do an internal audit, accepted an eight per cent reduction in its proposed indirect cost rate and restructured its accounting system to avoid overcharges in the future. The Defense Contract Audit Agency (DCAA), which is responsible for overseeing Stanford's government billing, has recommended that the university's indirect cost rate be cut further, to 52 per cent, and that all the special accounting exemptions be cancelled.

Fred Newton, deputy director of DCAA, testified that, as a result of a review of indirect cost billing at other universities, the California Institute of Technology had also withdrawn $\$ 500,000$ in overhead charges. SPACE RESEARCH

\title{
Space Station takes a blow
}

\section{Washington}

THE Space Station, a \$37,000-million project that has been advertised primarily as a research laboratory throughout its eightyear design history, can no longer be justified on scientific grounds, according to a new $\mathrm{Na}$ tional Research Council report.

Over the past year, the National Aeronautics and Space Administration (NASA) has been forced by congressional budget pressures to reduce the station's design capabilities and cut costs, which have more than doubled since the project was first proposed. The latest redesign, in response to a congressional directive to trim $\$ 6,000$ million from the space station programme, would reduce electric power, crew size and physical laboratory space - at the cost of its research capability, the NRC panel found. "Space Station Freedom, at the present state of redesign, does not meet the basic research requirement of the principal scientific discipline for which it is intended: (1) life sciences research $\ldots$ and (2) microgravity research and application", the report states.

In particular, the redesigned station will not carry enough crew members to conduct experiments in a reasonable time (the crew was recently halved to four), will not have enough electrical power or computer resources to run experiments and process data, and will not approach the near-weightless environment required for microgravity materials research, NRC said.

The devastating report may provide the ammunition some members of Congress have been looking for to cancel the project,
Dingell's subcommittee, which has jurisdiction over research funded by the National Institutes of Health (NIH) and other federal research agencies, is best known for its investigations of excessive indirect-cost rates among defence contractors.

Research universities are no less prone to accounting abuses, Dingell said. "In the beginning of this investigation, we believed we had the same ingredients for disaster. Unfortunately for the taxpayers, our worst fears appear to be coming true."

Stanford president Donald Kennedy testified at the hearing that accounting errors had allowed portions of his wedding celebration and depreciation on donated silverware to be charged to research accounts. "We have a problem, and we're taking it seriously", he said.

Under increasing pressure to rescue Stanford's tarnished image, Kennedy has recently announced that the university will shift emphasis away from research and towards teaching (see Nature 350, 5; 7 March 1991). New programmes, totalling some $\$ 7$ million, will offer financial rewards for excellence in teaching rather than research.

Christopher Anderson

says Robert Park, director of the American Physical Society's Washington Office. "I get the feeling that the wolves are smelling blood and starting to circle", he says.

While the research community has increasingly turned against the Space Station as its costs climbed and its potential scientific payoff waned, the NRC report is the strongest and most shocking condemnation yet.

NASA now finds itself in a difficult - and perhaps untenable - situation, with support for the project quickly evaporating almost everywhere outside the aerospace industry. Last year, concern over the impossible number of space walks that would be required to maintain the station forced NASA to schedule a complete redesign, the second major restructuring in less than a year (see Nature 344, 367; 1990). (No construction has begun for the project, which is currently scheduled to be in orbit by 1996.)

The current redesign process alone is costing $\$ 2,500$ million a year, more than the entire budget for the National Science Foundation, Park notes.

A recent internal report by the White House Office of Science and Technology Policy (OSTP) to Vice-President Dan Quayle, head of the National Space Council, was also critical of the space station's scientific usefulness. But the OSTP report suggested that some relatively minor modifications could make the station usable as a laboratory to study the way humans respond to long space flights, which might serve as at least one much-needed justification for the project. 